\title{
Kerkeberade: Het dit 'n plek \\ in die Gereformeerde kerkregering?
}

\author{
E P J Kleynhans \\ Universiteit van die Oranje-Vrystaat
}

\begin{abstract}
Church conferences: Does the Reformed Church government have room for it?

The National Conference of Church Leaders in South Africa, held at Rustenburg in 1990, like the Cottesloe Conference in December 1960, caused a violent reaction, especially amongst members of the Dutch Reformed Church. As a matter of fact, a considerable number of members resigned in protest against what happened at Rustenburg. The question of whether such a conference could fit in with the principles of Reformed Ecclesiastical government came strongly to the fore. This question is dealt with in the article.
\end{abstract}

Om by geleentheid van die emeritering van Prof Pont ' $n$ woord te mag meespreek, is 'n besondere voorreg. Ons het hom leer ken as ' $n$ kundige op die terrein van die Kerkgeskiedenis en Kerkreg, maar veral ook as lojale en behoudende kollega en goeie vriend. Van sy publikasies kon met vrug en waardering gebruik gemaak word.

Die saak waaroor dit in die onderhawige artikel gaan, is in 'n groot mate 'n stuk eietydse geskiedenis. Dit het ewenwel ook diepgrypende kerkregtelike fasette waarvan, glo ons, hy nie maar net in die verbygaan kennis geneem het nie.

Onder die opskrif 'Cottesloe - ná 30 jaar' maak die inleidingsartikel van Die Kerkbode (6 Julie 1990) die stelling dat Cottesloe ná dertig jaar 'weer met ons' is. Die kerkeberaad wat in 1960 onder voorsitterskap van ampsdraers van die Wèreldraad van Kerke in die Cottesloe-koshuis van die Witwatersrandse Universiteit ge- 
hou is - 'en wat die kerkboot destyds gevaarlik laat kantel het' - was weer in die kollig. Die blad maak melding van berade 'wat vir later vanjaar beoog word', waar die Suid-Afrikaanse Raad van Kerke, naas ander sake, glo ook 'Cottesloe' met afgevaardigdes van die Nederduitse Gereformeerde Kerk wil bespreek.

'n Seminaar wat deur die Sentrum vir Voortgesette Teologiese Opleiding op 12 September 1990 by die Universiteit van Pretoria aangebied is, gaan eweneens uit van die oortuiging dat Cottesloe 'vandag opnuut in die brandpunt' staan. Die oogmerk van die seminaar oor 'Cottesloe - ná 30 jaar' is derhalwe 'om die geskiedenis in herinnering te roep sodat ons mense beter toegerus kan wees om die jongste gesprekke te volg en daaraan deel te neem'.

Feit is dat daar, na dertig jaar, weer 'n kerkeberaad op Suid-Afrikaanse bodem in die vooruitsig was. In die eerste uitgawe van Die Kerkbode in 1990 spreek prof Johan Heyns, voorsitter van die Algemene Sinodale Kommissie van die Nederduitse Gereformeerde Kerk, na aanleiding van staatspresident $F$ W de Klerk se uitnodiging in sy Kersboodskap aan alle kerke 'om deel te neem aan die onderhandelingsproses', sy dank uit vir die geleentheid wat aan die kerk gegee word om 'n bydrae te lewer in hierdie tyd: 'Daar is geen twyfel dat die Ned Geref Kerk sy volle samewerking sal gee nie' (Heyns 1990).

Die beplande kerkeberaad vind plaas in 'n hotel te Hunter's Rest naby Rustenburg op 5-9 November 1990. In 'n terugblik op die beraad skryf dr Louw Alberts, mede-voorsitter van die konferensie, dat nagenoeg 230 deelnemers, 'hoofsaaklik verteenwoordigend van die kerke en in ' $n$ mindere mate van die belangrikste sending- en interkerklike organisasies' aanwesig was. Die Nederduitsch Hervormde Kerk van Afrika en die Afrikaanse Protestantse Kerk het nie die uitnodiging aanvaar nie. Die beraad het hoofsaaklik 'om die sosio-politiese vraagstukke van SuidAfrika gewentel'. Hy bestempel die persoonlike belydenis van Prof Willie Jonker as 'n 'hoogtepunt in die beraad' (Alberts 1990:5). Hierdie belydenis, wat deur die afvaardiging van die Nederduitse Gereformeerde Kerk beaam is, lui soos volg:

I confess before you and before the Lord, not only my own sin and guilt, and my personal responsibility for the political, social, economical and structural wrongs that have been done to many of you and the results of which you and our whole country are still suffering from, but vicariously I dare also to do that in the name of the NGK of which I am a member, and for the Afrikaans people as a whole. I have the liberty to do just that, because the NGK at its latest synod has declared apartheid a sin and confessed its own guilt of negligence in not warning against it and distancing itself from it long ago.

(Jonker 1990:5) 
Dr Alberts maak ook melding van die breedvoerige bespreking van 'herstel en restitusie' en dat dit in 'die uiteindelike Rustenburg deklarasie' neerslag gevind het in die vorm van ' $n$ aantal aanbevelings 'waarvan sommige in 'n mate 'n politieke kleur aangeneem het' (Alberts 1990:4).

Soos die Cottesloeberaad in 1960, het ook die Rustenburgberaad heftige reaksie, veral in die geledere van die Nederduitse Gereformeerde Kerk ontketen. In wye kringe is dit met protes begroet en talle lidmate het as gevolg daarvan hulle lidmaatskap van die Nederduitse Gereformeerde Kerk beëindig. Die vraag oor die wenslikheid, al dan nie, van sodanige kerkeberade het by vele ontstaan. Het kerkeberade 'n plek in die Gereformeerde kerkregering?

Teen die agtergrond van die gebeure by Cottesloe en Rustenburg word hier, vanuit 'n kerkregtelike gesighoek, aan hierdie vraag aandag gegee.

\section{DIE BEGINSEL VAN SOEWEREINITEIT IN EIE KRING}

Die Gereformeerde stelsel van kerkregering handhaaf die selfstandigheid van die kerk naas die staat. In die uitbouing van hierdie stelsel is voor alles die oorheersing van die staat deur die kerk, soos voorgestaan deur die Roomse stelsel, afgewys. Aan die ander kant is ook teen die oorheersing van, of seggenskap in die regering van die kerk deur die staat, standpunt ingeneem. Die uitgangspunt by Gereformeerdes in hierdie verband is die beskouing van Calvyn wat, volgens die beginsel van soewereiniteit in eie kring, ' $n$ vrye kerk in 'n vrye staat wil sien sodat die owerheid, soos die kerk, as instelling van God tot sy reg kom (Calvyn sa:IV, XX, 1-32). Hierdie standpunt is ook gangbaar by kerke met 'n Gereformeerde belydenis in Suid-Afrika.

In die Verklaring van die Kerkeberaad by Cottesloe (Lückhoff 1978:83-92) word vermeld dat 'die Christelike standpunt ten opsigte van rasseverhoudinge' as algemene onderwerp van bespreking gedien het. Meer bepaald het dit gegaan oor 'die ingewikkelde vraagstukke in verband met menslike verhoudinge in Suid-Afrika'. Met so 'n agenda was dit te verwagte dat die praktiese politiek op verskillende punte direk geraak sou word. Besluite wat geneem is oor sake soos die verbod op rasgemengde huwelike, direkte verteenwoordiging van Kleurlinge in die Parlement, trekarbeid, werkreservering en die reg van stedelike swartes tot grondbesit en deelname in die landsregering dui daarop dat die Kerkeberaad sy bevoegdheidsgrense oorskry en op die terrein van die staat beweeg het.

Om hierdie rede het die Nederduitsch Hervormde Kerk, wat van meet af krities teenoor die Beraad gestaan het, hom vóor die beëindiging van die samesprekings reeds volkome van die bevindinge gedistansieer. In 'n latere verklaring stel dié Kerk dit onomwonde dat dit nie die taak van die kerk is 'om aan die Regering voor 
te skryf hoe die Kleurlinge of enige ander rassegroep verteenwoordig moet word of watter politieke regte hulle moet geniet nie' (Die Bunger 16 Desember 1960:1, 9).

So het die Nederduitse Gereformeerde Kerk hom ook by monde van die Sinodes wat op Cottesloe gevolg het daaroor uitgespreek. Die Nederduitse Gereformeerde Kerk in Suidwes-Afrika, wat op 1 Maart 1961 vergader het, was van oordeel dat die Kerkeberaad die politieke arena betree het en so, in plaas van om leiding te gee, verdeeldheid onder lidmate gesaai het (Handelinge Sinode Suidwes-Afrika 1961:48, 49). Sterker nog is die uitspraak van die Transvaalse Sinode (Handelinge Sinode Transvaal 1961:382) in hierdie verband: 'Die Sinode keur die beoordeling van die Owerheidsbeleid op hierdie wyse en langs hierdie weg ten sterkste af, aangesien dit die Owerheid in die uitvoering van sy moeilike taak onnodig in verleentheid gebring het...juis...op die ongelukkige tydstip toe Suid-Afrika in die brandpunt van vyandelike aanvalle gestaan het.'

Ook die Raad van die Kerke en die Kaapse Sinode was van oordeel dat 'n 'groot aantal van die resolusies handel oor sake van die praktiese politiek waaroor die Kerk as instituut hom nie behoort uit te spreek nie tensy een of ander duidelike Skrifbeginsel in die gedrang kom' en betreur daarby die 'kritiek op die landsbeleid' wat 'van hierdie verhoog af uitgebring is, terwyl die Kerk nog altyd toegang tot die Regering gehad het om oor enige saak te spreek' (Handelinge Raad van die Kerke 1961:54, 55; Sinode Kaapland 1961:50, 51).

Die Kerkbode $(1960: 916,917)$, amptelike orgaan van die Nederduitse Gereformeerde Kerk, vat die standpunt van die Kerk met betrekking tot die Cottesloeverklaring korrek soos volg saam: 'Die prediking van geregtigheid op maatskaplike en politieke terrein bly die verantwoordelikheid van die Kerk, maar wanneer hy hom met politieke formules inlaat, is dit 'n ontoelaatbare "staatsgreep".'

Dit is van betekenis dat die Cottesloeberaad en wat daarmee gepaard gegaan het by die sinodes van al vyf die destydse Gefedereerde Nederduitse Gereformeerde Kerke ter sprake gekom het en afgewys is.

Die gedagte, waarvoor Cottesloe gestaan het, het ewenwel by sommige bly voortlewe. Hoewel beide die Kaapse en die Transvaalse Kerke hulle verbintenisse met die Wêreldraad van Kerke in 1961 verbreek het, is die beinvloeding vanuit hierdie oord in Suid-Afrika voortgesit. Die Christenraad van Suid-Afrika wat reeds in die dertigerjare tot stand gekom het, besluit in 1962 om met die Wêreldraad van Kerke te affilieer. Daarmee het hy hom ook met die breër ekumeniese siening van dié wèreldliggaam vereenselwig. Dat dié stap groter verwydering tussen die Christenraad en die Afrikaanssprekende kerke in Suid-Afrika sou bring, le voor die hand. Gebeurtenisse in die jaar 1968 sou dié verwydering verder verdiep. 'n Nuwe grondwet, wat tydens die jaarvergadering van 1968 aanvaar is, het bepaal dat die naam 
van die Christenraad na die Suid-Afrikaanse Raad van Kerke (SARK) verander word. Met die naam is ook die beleid van die SARK ingrypend verander. Die 'sendingfase' van die lidkerke, waarin veral op persoonlike saligmaking en bekering gekonsentreer is, was verby. Daar sou voortaan 'n baie groter betrokkenheid by maatskaplike, ekonomiese en politieke vraagstukke van die land wees. Hierdie koerswysiging dra tewens daartoe by dat die Baptiste Kerk, die Heilsleër en The Church of the Nazarene hulle lidmaatskap van die SARK beëindig. ' $n$ Vlugskrif, onder die titel Boodskap aan die Volk van Suid-Afrika, wat 'n uitvloeisel was van 'n konferensie wat die Wêreldraad van Kerke oor die onderwerp 'Church and Society' in 1966 in Genève gehou het, is in 1968 vrygestel en oor 'n wye front versprei. Dit was bereken om die klemverskuiwing verder wèreldkundig te maak en het heelwat reaksie en kritiek uitgelok (Kleynhans 1985:134).

Op 11 en 12 September 1985 is 'n veelrassige byeenkoms in Pietermaritzburg gehou. Dit is bygewoon deur sowat vyftig predikante en teoloë van die Nederduitse Gereformeerde Kerk, van wie sommige ook referate gelewer het oor die tema 'Nasionale inisiatief vir versoening'. Volgens die verklaring wat ná die byeenkoms uitgereik is, was die doelstelling daarvan om Suid-Afrika in ' $n$ 'totally non-racial land' te help omskep. Hier reeds gee predikante van die Nederduitse Gereformeerde Kerk hulle berou te kenne 'or die wyse waarop ons die eenheid van die kerk geskend het, sowel binne ons eie kerk as in breër ekumeniese verband in Suid-Afrika' (Potgieter 1990:19).

Veel skerper kom die veroordeling van die staatkundige beleid in Suid-Afrika na vore by die Vereenigingberaad (6-10 Maart 1989). 'n Verklaring, uitgereik by dié Beraad en bekend as 'The Testimony of Vereeniging', lui soos volg: 'We say clearly and unequivocally that we regard apartheid in all its forms as a sin, as contrary to and irreconcilable with the Gospel of Jesus Christ. We agree that apartheid in all its forms cannot be reformed, but must be totally eradicated from the life of the South African nation and church' (vgl Handelinge Algemene Sinode 1990:45, 46). Die Algemene Sinode van 1990 distansieer hom van hierdie verklaring (Handelinge Algemene Sinode 1990:429, 680).

Die 'Rustenburg Declaration' vind in sy aanhef noue aansluiting by die standpunt wat by Vereeniging ingeneem is: '...on this we are all agreed, namely the unequivocal rejection of apartheid as a sin' (The Rustenburg Declaration 1990:1).

As dr Louw Alberts toegee dat sommige van die aanbevelings 'in 'n mate 'n politieke kleur aangeneem het', stel hy dit sag. Politieke strydvrae van die dag, soos die daarstelling van 'n demokratiese verkiesingsproses gebaseer op een mens, een stem, op 'n gemeenskaplike kieserslys, in 'n veelpartydemokrasie in 'n eenheidstaat, onderhandeling oor 'n nuwe grondwet deur 'n liggaam wat duidelik en ten volle ver- 
teenwoordigend van alle Suid-Afrikaners is, die daarstelling van 'n vorm van administrasie of regering wat sal verseker dat die belange van alle Suid-Afrikaners behoorlik verteenwoordig word in die oorgangstydperk totdat daar oor 'n nuwe grondwet ooreengekom word, die herroeping van alle apartheidswette, onvoorwaardelike vrywaring aan politieke uitgewekenes, die onmiddellike vrylating van alle politieke gevangenes en die teruggawe van die gekonfiskeerde eiendom van organisasies wat vroeër verban was, is onder die sake wat aangespreek is (The Rustenburg Declaration 1990:4-6).

Met goeie reg bestempel dr Albu van Eeden die Rustenburgdeklarasie as 'n 'gematigde of afgewaterde weergawe...van die beleid uiteengesit in die Kairos-dokument, die latere "Evangelical Witness" en die "Road to Damascus"'. Hy wys ook met ontsteltenis op die 'ooglopende, amper blatante sosialistiese onderstroom' soos dit in die volgende sinsnedes deurklink: 'We affirm and highlight the following:...More equitable wealth distribution must go hand in hand with economi: growth' en 'As a first step towards restitution the church must examine its land ownership and work for the return of all land ex-propriated from communities to its original owners' (Van Eeden 1991:8).

Die blote feit dat die Rustenburgberaad op inisiatief van staatspresident $F$ W de Klerk plaasgevind het en dat, na afloop daarvan, aan hom verslag daaromtrent gedoen is (Die Burger 15 Maart 1991:15), het die indruk by vele kerklidmate gelaat dat die kerk aan die staat dienstig gemaak is vir die deurvoering van die hervormingsplanne wat aan die orde van die dag is. Soos by Cottesloe is die beginsel van soewereiniteit in eie kring in die proses verkrag. Die goeie gereformeerde stelreël, reeds by die Sinode van Dordrecht in 1574 neergelê, dat kerklike vergaderinge hulle net met kerklike sake besig moet hou (Hooijer 1865:95), het eweneens in die gedrang gekom. Spoelstra (1991:5) het rede om daaroor te skryf: 'Godsdiens en politiek het in 'n taamlike duister "huwelik" geraak.'

\section{KERKREGERING DEUR KERKVERGADERINGE}

Die vraag of kerkeberade hoegenaamd as kerkvergaderinge kwalifiseer, verdien vervolgens ons aandag.

Op voetspoor van Calvyn (1900:Il, 11) is die grondwaarheid waarvan die Gereformeerde Kerkreg uitgaan, dat Jesus Christus die Hoof en Heer van sy kerk is en as Koning direk en persoonlik daaroor regeer. Op die vraag hoe die Christusregering in die kerk konkreet gerealiseer word, leer hy (Calvyn sa:IV, III, 1) in die lig van Efesiërs 4 en 1 Timoteus 3, gesteun deur 'n hele aantal ander Skrifgedeeltes, dat die Here enersyds alleen in sy kerk regeer en wel deur sy Woord. Aangesien Hy egter 
nie in sigbare gedaante onder ons woon en dus nie in eie persoon en mondeling sy wil aan ons bekend maak nie, maak Hy andersyds hiervoor van die diens van mense gebruik. Hierdie diens word ook onder die benaming van ampte tuisgebring.

Dit is opvallend dat die Skrif in die reël van die ouderling in die meenoud praat (vgl Hand 11:30; 14:23; 15:6; 20:17; 21:18; 22:5; 24:1; Fil 1:1; 1 Tim 5:17; Tit 1:5; Op $4: 4 ; 5: 5 ; 7: 11 ; 14: 3)$. Uitgaande van hierdie Skriftuurlike riglyn, leer $H$ Bouwman (1928:551) met goeie reg dit 'een ouderling alleen, evenmin als de predikant afzonderlijk' in die kerkregering 'tot geen beslissende daad bevoegd' is nie, 'slechts in vereeniging met elkander en met den dienaar vormen zij den raad der kerk, en zijn zij tot de regeering bevoegd'.

Die uitoefening van die Christusregering deur middel van ampte lei dus tot die aanwending van kerkvergaderinge as regeerliggame. Hierdie vergaderinge het, elkeen na sy aard, 'n kerklike gesag, deur Christus aan hulle verleen. Derhalwe is hulle die amptelike regeerliggame van die kerk en is hulle besluite bindend. Geen persoon of groep persone, ook nie die kommissies van die kerk mag hulle die reg aanmatig om na willekeur namens die kerk besluite te neem en uitsprake te maak nie. Dit doen gereformeerde kerke slegs deur hulle vergaderinge (Botha 1987:269). En hierdie vergaderinge word uitdruklik in hulle kerkordes vermeld (vgl Fourie 1982:5; NHKA Kerkwet 1979:arts 4, 7, 13; Van der Linde 1983:118).

Kerkeberade, soos dié by Cottesloe en Rustenburg, kwalifiseer in geen opsig as amptelike regeerliggame van gereformeerde kerke nie. Selfs uit 'n ekumeniese gesigshoek staan dit op wankele gronde. 'n Ekumeniese Sinode of Raad wat bindende besluite kan neem, is ondenkbaar. Die rede lê voor die hand: Die beginsel van verteenwoordiging van die plaaslike kerke kom op verre na nie tot sy reg nie (Potgieter 1978:31).

Daarbenewens was Gereformeerdes nog steeds gesteld op die suiwere leer as grondslag en voorvereiste vir ekumeniese betrekkinge. Vir Calvyn, van wie Praamsma (sa:206) praat as 'de klassieke strijder voor de eenheid der kerk', is die onvervalste leer, die waarheid in Christus, die primêre grond vir kerklike eenheid. Sy duidelike grense en voorbehoude in alle betrekkinge met Rome en doperse sektes getuig van sy onwil tot kompromie ten opsigte van die waarheid. Die suiwere leer is die konsentriese middelpunt waarvandaan sy optrede uitgaan (Hanekom 1964:154).

Volgens die presensielys was 46 'organisasies' by die Rustenburgberaad verteenwoordig. Vyftien van hierdie organisasies word nie eens in die SA Christian Handbook 1990) vermeld nie, terwyl tien deelnemers aan die Beraad klaarblyklik geen bepaalde kerk of organisasie verteenwoordig het nie (United Christian Action, 1990). Dat hierdie Kerkeberaad, binne die riglyne wat die Kerkorde van die Nederduitse 
Gereformeerde Kerk vir ekumeniese betrekkinge neerlê, nie ingepas kan word nie, moet vir elkeen duidelik wees.

\section{OORSKRYDING VAN BEVOEGDHEID}

Die vraag of ' $n$ lid, of lede van 'n kerkeberaad die bevoegdheid het om, na aanleiding van besprekings wat op die onderhawige beraad gevoer is, namens die kerk wat hulle verteenwoordig, verklaringe uit te reik, vloei uit voornoemde voort.

Ten tye van die Cottesioeberaad het die Nederduitse Gereformeerde Kerk hom in sy kerkregering van drie vergaderinge bedien: die Kerkraad, Ring en Sinode. Kragtens hulle verantwoordelikheid vir sake van gemeenskaplike belang (res generales) was die twee betrokke sinodes met ekumeniese aangeleenthede, soos die samespreking met verteenwoordigers van die Wêreldraad van Kerke, gemoeid. Afgevaardigdes na die Beraad by Cottesloe is ewenwel nie deur dié sinodes aangewys nie. Die onderskeie Moderature neem die inisiatief in die voorbereiding vir die Beraad en benoem ook die aanvanklike studiekommissies en uiteindelike afgevaardigdes (Handelinge Sinode Kaapland 1961:187; Handelinge Sinode Tranvaal 1961:82). Dit kan in die besondere omstandighede begryp en verskoon word. Die kerkordelike weg was nietemin dat die afgevaardigdes hulle verslag oor die verloop van die Beraad aan hulle eie Sinode sou voorlê en dit aan die Sinode, wat daartoe die bevoegdheid het, moes oorlaat om uitspraak daaroor te doen. Die Sinodes van sowel Kaapland as Transvaal sou in 1961 vir hulle gewone vierjaarlikse vergaderinge saamkom en daar sou dus nie 'n te lang tydsverloop wees voordat die besluite die nodige aandag kon geniet nie.

In die lig daarvan is dit begryplik dat die Transvaalse Sinode van 1961 hom soos volg uitspreek: 'Die Sinode betreur die neem en bekendmaking van ingrypende besluite soos die deur die Kerkeberaad te Cottesloe geneem alvorens 'n bevoegde kerklike vergadering hulle in behandeling kon neem en besluit dat al die bevindings wat in botsing is met ons Kerk se geformuleerde beleid nie aanneemlik is vir hierdie vergadering nie' (Handelinge Sinode Transvaal 1961:382). Ook die Kaapse Sinode betreur dit 'dat die bevindinge van die Kerkekonferensie wereldkundig gemaak is voordat ons kerke deur hul vergaderinge geleentheid gehad het om hulle daaroor uit te spreek' (Handelinge Sinode Kaapland 1961:51).

Uit kerkregtelike gesigshoek was die destydse Suid-Afrikaanse Eerste Minister, dr H F Verwoerd, korrek toe hy in sy Nuwejaarsboodskap van 1961 daarop gewys het dat die besluite van Cottesloe nog nie amptelike uitsprake van die kerke was nie. Lückhoff (1978:163-167) is van oordeel dat die Nasionale Party en die bepaalde tydsgewrig waarin die Cottesloebevindinge bekend gemaak is, bygedra het tot die 
skerp reaksie van die Nederduitse Gereformeerde Kerk daarop. Hy maak veral veel van die gemelde radioboodskap vir die Nuwejaar wat dr Verwoerd op 31 Desember 1960 gelewer het. Daarmee, skryf Lückhoff, het 'n 'nie-kerklike instansie van die hoogste gesag' in die gang van sake 'ingegryp': 'Hy het onomwonde verklaar dat hy Cottesloe beskou as 'n poging van buitelanders om hulle in interne Suid-Afrikaanse aangeleenthede in te meng. Verwoerd het die besluite verwerp as komende van 'n aantal enkelinge uit die NG Kerke.' Volgens Lückhoff het hierdie uitspraak van die Premier 'die georganiseerde veldtog teen Cottesloe ingelei...Die lidmate van die NG Kerke is hierdeur met nog 'n keuse gekonfronteer: tussen die leiding van Verwoerd en die Nasionale Party en die leiding van die NG Kerkleiers wat Cottesloe bygewoon het'.

Die gewraakte Nuwejaarsboodskap is woordeliks en volledig in Die Volksblad van 3 Januarie 1961 opgeneem. Oor die Cottesloebevindinge het Verwoerd hom soos volg uitgelaat:

Ek is nie van plan om onlangse persoonlike verklarings oor kleurbeleid van individuele kerkmanne te behandel nie. Die indruk wat geskep is deur teenstanders van die beleid van afsonderlike ontwikkeling dat sekere kerke daarteen standpunt ingeneem het, is immers geheel en al verkeerd. Die kerk het inderdaad nog glad nie gepraat nie. Deur hul[le] sinodes wąarop al die leraars en die lede verteenwoordig sal wees, moet die kerke se stemme nog gehoor word. Ek wil graag die hoop uitspreek dat nou sal opgehou word met die onregmatige insleep van die name van ons kerke in 'n debat wat op die oomblik net deur individue in hul eie naam gevoer kan word.

(Die Volksblad 1961:6, 7)

Wie nou die werklike woorde van Verwoerd vergelyk met Lückhoff se weergawe daarvan, sal saamstem dat hy woorde in die mond van die Premier gelê het wat hy nie uitgespreek het nie. Laasgenoemde het miskien rede gehad om te vermoed dat die Cottesloeberaad 'n poging van buitelanders - en Suid-Afrikaanse kerkmanne was om in Suid-Afrikaanse sosio-politieke aangeleenthede in te meng, maar in soveel woorde het hy dit nie gesê nie. Hy het hom uitdruklik daarvan weerhou om op die bevindinge van Cottesloe in te gaan. Hy het dit slegs oor die optrede van die afgevaardigdes gehad, wat inderdaad hulle kerklike bevoegdheid oorskry het. Kerkregtelik gesien, was die Premier korrek en het hy tewens 'n tydige woord gespreek.

In die gebeure ná Cottesloe het die Nederduitse Gereformeerde Kerk op die gereformeerde spoor voortbeweeg. Enersyds het hy geweier om, op aandrang van buite, voorskriftelik teenoor die owerheid met betrekking tot politieke aangeleenthede op te tree, andersyds was hy nie maar net dienstig aan die owerheid om die se 
beleid voetstoots na te volg nie. Sowel die Roomse as die Erastiaanse uiterstes is in die proses afgewys. Die selfstandigheid van die kerk teenoor die staat èn van die staat teenoor die kerk is gehandhaaf.

Die ongelukkige geskiedenis van Cottesloe het homself in 'n groot mate by die Rustenburgberaad van 1990 herhaal. Die Algemene Sinodale Kommissie rapporteer aan die Algemene Sinode van die Nederduitse Gereformeerde Kerk in 1990 dat ongeveer 200 afgevaardigdes van kerke en godsdienstige instansies na aanleiding van die Staatspresident se Kersfeesboodskap, op 20 en 21 Julie 1990 te Pretoria byeengekom het. Die Nederduitse Gereformeerde Kerk was verteenwoordig deur prof J A Heyns, ds D J Viljoen, prof P C Potgieter, dr D J Hattingh en dr P Rossouw. Hierdie beraad wat, met enkele uitsonderings, nie deur kerke van die SARK bygewoon is nie, is gesien 'as 'n voorlopige voorbereidende byeenkoms vir 'n groter beraad waarby die SARK ook teenwoordig sal wees in November'. Die teenwoordigheid van 'n afvaardiging van die Nederduitse Gereformeerde Kerk by daardie geleentheid is ook in vooruitsig gestel. 'Omrede die tydfaktor en ter wille van kontinuiteit, is die name van dieselfde afvaardiging...opgestuur vir die tweede groter beraad in November. Die nuwe Dagbestuur kan egter vakatures aanvul of veranderings aanbring indien nodig.' Die Algemene Sinode het hiervan kennis geneem (Handelinge Algemene Sinode 1990:466, 554). Nêrens elders was dit ter sprake nie. Daar was ook nie sprake van enige bepaalde opdrag wat aan die afvaardiging, wat uiteindelik bestaan het uit prof $P$ C Potgieter en drr D J Hattingh, F M Gaum en P Rossouw, deur die Algemene Sinode gegee is nie.

Op 19 November 1990 wys prof P B van der Watt tereg in Die Transvaler daarop dat die 'opsienbarende belydenis' van prof Willie Jonker by die Rustenburgberaad die Nederduitse Gereformeerde Kerk 'aan die praat èn protes gesit' het. Hy voeg daaraan toe: 'Myns insiens het die professor kerkregtelik geen reg gehad om sy persoonlike belydenis ook namens die NGK te doen nie en om dit ook namens die Afrikanervolk te doen, doen erg aanmatigend aan' (Van der Watt 1990). Vier dae tevore reeds het dr S J Eloff in die Die Volksblad soos volg geskryf:

As afgevaardigde ouderling by die Algemene Sinode beweer ek dat prof Willie Jonker se siening en belydenis van apartheid nie dieselfde is as die Algemene Sinode s'n nie...Die lidmate van die NG Kerk sal hulle nie deur die persoonlike belydenis van prof Jonker op sleeptou en van koers af laat neem nie. 'n Baie groot deel van die Afrikaners (namens wie hy ook belydenis wou doen) aanvaar hom nie as bemiddelaar wat hulle belydenis aan ander moet oordra nie.

(Eloff 1990) 
In 'n verklaring oor die Rustenburgbelydenis wys die vier moderature van die Transvaalse Sinodes op 16 November 1990 lidmate daarop

dat by die beoordeling van die belydenis van prof Jonker op die volgende gelet moet word:

1. Hy was nie 'n amptelike afgevaardigde van die Ned Geref Kerk nie;

2. Hy het geen amptelike opdrag tot so 'n belydenis gehad nie;

3. Sy belydenis ten opsigte van apartheid moet beoordeel word in die lig van die besluite van die Algemene Sinode.

(Verklaring oor Rustenburgbelydenis 16 November 1990)

Die Algemene Sinodale Kommissie van die Nederduitse Gereformeerde Kerk vergader op 4 Desember 1990 om besondere aandag te gee aan die besluite van die Algemene Sinode en die Rustenburgse kerkeberaad. Die vergadering boekstaaf dit dat prof Jonker nie 'n amptelike afgevaardigde van die Nederduitse Gereformeerde Kerk was nie en dat hy nie 'n opdrag gehad het om namens dié Kerk 'n skuldbelydenis te doen nie. Die ASK oordeel dat prof Jonker hom, in sy belydenis oor apartheid, op die besluite van die Algemene Sinode beroep het, 'ofskoon hy nie die hele verband van die Sinode se besluite vermeld het nie'. Die vergadering is verder van oordeel dat die afvaardiging van die Nederduitse Gereformeerde Kerk met hulle verklaring tydens die Kerkeberad by die besluite van die Algemene Sinode gebly het, hoewel ook hulle 'nie die hele verband van die Sinode se besluite vermeld het nie. Dit kon by lidmate verwarring veroorsaak het'. Voorts neem die ASK kennis van die Deklarasie van Rustenburg 'en onderskryf die voorbehoude van die afvaardiging van die Ned Geref Kerk daaroor'. Ten slotte beklemtoon die ASK 'met groot erns dat die mate van onrustigheid wat tans in die Ned Geref Kerk aanwesig is, ons almal tot diepe verootmoediging voor die Here oproep' (Verklaring van die ASK 4 Desember 1990; Die Kerkbode 14 Desember 1990).

Met die lewering van 'n skuldbelydenis namens die Nederduitse Gereformeerde Kerk deur prof Jonker, die uitreiking van 'n verklaring namens die Nederduitse Gereformeerde Kerk deur die afvaardiging en hulle deelname aan die opstel en uitreiking van die Rustenburgse Deklarasie - al was dit met voorbehoud - is die grense van hulle hevoegdheid stellig oortree. Wat die gewraakte Deklarasie betref, het die afvaardiging tot op datum in gebreke gebly om 'n presiese aanduiding te gee van die klousules waarteen hy beswaar het. By sy vergadering op 1 Februarie 1991 het die Dagbestuur van die ASK bevestig dat die voorbehoude van die afvaardiging gehandhaaf bly: 'Die Dagbestuur wou egter nie daarop uitbrei en die voorbehoude in groter besonderhede omskryf nic.' Die Deklarasie is na die Algemene Kommissie vir leer en Aktuele Sake verwys om te bestudeer en verslag te lewer (Die Kerkbode 
1991:1). Dit beteken dat diegene wat belang daarby het, waarskynlik tot in 1994 sal moet wag om te weet op welke van die vele punte wat lynreg teen die geformuleerde beleid van die Nederduitse Gereformeerde Kerk ingaan, die afvaardiging van die res van die Beraad verskil het.

Juis in die uitgawe van 7 Desember 1991 haal Die Kerkbode aan uit die Die Kerkblad, amptelike orgaan van die Gereformeerde Kerke in Suid-Afrika (GKSA), oor dié Kerk se betrokkenheid by die Rustenburgberaad:

Volgens ds C J Malan, voorsitter van die Deputate vir korrespondensie met die Owerheid, is die feite die volgende:

Die Staatspresident het die leiding van die GKSA gevra om hom advies oor die verhouding Kerk en Staat te gee.

Op grond hiervan het die Deputate met meerderheid van stemme aan prof J L Helberg opdrag gegee om die 'Kerkeberaad' namens die GKSA by te woon.

Oor hierdie saak sal die Deputate by die Nasionale Sinode in 1991 rapporteer.

(Die Kerkbode 7 Desember 1990)

Dit is jammer dat die afvaardiging van die Nederduitse Gerefomeerde Kerk nie ook eers ten minste aan die ASK gerapporteer het nie.

\section{SLOTSOM}

Die gegewens in die voorafgaande paragrawe lei tot die slotsom dat die tersaaklike gereformeerde beginsels by sowel die Cottesloese as Rustenburgse Kerkeberade erg in die gedrang gekom het. Skakeling tussen kerk en staat is natuurlik moontlik en in bepaalde omstandighede selfs noodsaaklik. Maar dan moet dié skakeling en die kontak of gesprek wat daaruit voortvloei op ordelike wyse geskied. Die Nederduitse Gereformeerde Kerk maak in sy Kerkorde genoegsame voorsiening vir skakeling op verskillende vlakke. Op die verantwoordelikheidsvlak van die Algemene Sinode geskied skakeling deur middel van die Kommissie vir skakeling met die owerheid, wat te alle tye gebind is aan die geformuleerde beleid en besluite van die Algemene Sinode en nie die bevoegdheid van die Sinode uit sy hande mag neem nie.

Juis omdat kerkeberade soos dié by Cottesloe en Rustenburg saamgestel word uit verteenwoordigers van kerke met uiteenlopende belydenisgrondslae, kerkordelike reëlinge en standpunte, is die versoeking tot ontoelaatbare kompromisse altyd groot. En ongelukkig is voor dié versoeking telkens geswig.

Op die vraag of kerkeberade 'n plek in die Gereformeerde kerkregering het, moet derhalwe afwysend geantwoord word. 


\section{Literatuurverwysings}

Alberts, L 1990. Terugblik op Rustenburg. Die Kerkbode 16 November 1990.

Botha, M C 1987. Die Kommissie-struktuur in die Nederduitse Gereformeerde Kerk. DD-proefskrif, Universiteit van Pretoria.

Bouwman, H 1928. Gereformeerd Kerkrecht I. Kampen: Kok.

Calvyn, J 1900. De Handelingen der Apostelen II. Vertaald door G Wielenga. Kampen: Kok.

--- sa. Institutie. Vertaald door A Sizoo. Delft: Naamloze Vennootschap W D Meinema.

Die Burger 1960. Ned Herv Kerk stel standpunte: Regering se optrede is regverdig. 16 Desember 1960: bladsy 1, 9.

--- 1991. SP, kerklui praat oor beraad. 15 Maart 1991, bladsy 15.

Die Kerkbode 1960. Die Kerke-Konferensie. Inleidingsartikel. 28 Desember 1960.

--- 1990. Cottesloe - ná 30 jaar. Inleidingsartikel. 6 Julie 1990.

--- 1990. Sienings. 7 Desember 1990.

--- 1990. Rustigheid in NG Kerk ná verklaring van Algemene Sinodale Kommissie. 14 Desember 1990.

-.- 1991. Rustenburg: voorbehoude bly. 8 Februarie 1991.

Die Volksblad 1961. Kerke se name onregmatig ingesleep. 3 Januarie 1961.

Eloff, S J 1990. Sinodebesluite oor apartheid. Die Volksblad 15 November 1990.

Fourie, D C G 1982. Die Kerkorde van die die Ned Geref Kerk. Pretoria: NG Kerkboekhandel.

Hanekom, T N 1964. Kerk en kerkbegrip by Calvyn. NGTT 3, 149-167.

Heyns, J A 1990. Nuwe dekade bring ook vir die kerk verandering. Die Kerkbode 12 Januarie 1990.

Hooijer, C 1865. Oude Kerkordeningen der Nederlandsche Hervormde Gemeenten. Zalt-Bommel: Noman \& Zoon.

Jonker, W D 1990. Understanding the Church situation: Obstacles to a united witness. National Church Leaders Conference Rustenburg 5-9 November 1990. Unpublished.

Kleynhans, E P J 1985. Gereformeerde Kerkreg 3. Pretoria: NG Kerkboekhandel.

Lückhoff, A H 1978. Verklaring van die Kerkeberaad by Cottesloe. Kaapstad: Tafelberg.

Nederduitsch Hervormde Kerk van Afrika 1979. Kerkwet en bepalings. Pretoria: KITAL.

Nederduitse Gereformeerde Kerk 1961. Handelinge van die Sinodes van Kaapland, Raad van die Kerke, Suidwes-Afrika en Transvaal. Pretoria: NG Kerk.

-.- 1990. Handelinge van die Algemene Sinode. Pretoria: NG Kerk. 
Nederduitse Gereformeerde Kerk 1990. Verklaring oor Rustenburgbelydenis, deur die vier Moderature van die Ned Geref Sinodes van Transvaal 16 November 1990. Pretoria: NG Kerk.

--- 1990. Verklaring van die ASK 4 Desember 1990. Pretoria: NG Kerk.

Potgieter, F J M 1978. Eenheid en veelvormigheid prinsipieel verantwoord, in Veelvormigheid en Eenheid, bladsye 9-36. Kaapstad: NG Kerk-Uitgewers.

--- 1990. Kerk en Samelewing - 'n Wesenskou. Kaapstad: NG Kerk-Uitgewers.

Praamsma, L sa. Calvijn. Wageningen: Zomer \& Keunings.

Spoelstra, B 1991. Verwarring oor skuldbelydenis. Die Kerkblad 16 Januarie 1991.

The Rustenburg Declaration 1990. Unpublished.

United Christian Action 1990. Organisations represented at the National Conference of Churches, Rustenburg. Unpublished.

Van der Linde, G P L 1983. Die Kerkorde: 'n Verklaring van die Gereformeerde Kerkorde. Potchefstroom: Potchefstroomse Teologiese Studies.

Van der Watt, P B 1990. Belydenis - hoekom nou al die trane? Die Transvaler 19 November 1990.

Van Eeden, A 1991. Rustenburg klink soos Kairos. Die Kerkhode 25 Januarie 1991. 